\title{
THE RISK OF STRIKING ACCIDENTS DURING LPG SHIPS PASSAGE IN PORTS IN RESPECT TO TECHNICAL FAILURES BASED ON REAL TIME SIMULATIONS IN SZCZECIN-ŚWINOUJŚCIE WATERWAY
}

\author{
RYZYKO WYPADKU PODCZAS PRZEJŚCIA \\ JEDNOSTEK Z LADUNKIEM NIEBEZPIECZNYM \\ W PORTACH W ASPEKCIE AWARII URZĄDZEŃ \\ TECHNICZNYCH NA PRZYKLADZIE JEDNOSTEK LPG \\ MANEWRUJĄCYCH W KOMPLEKSIE PORTOWYM \\ SZCZECIN-ŚWINOUJŚCIE
}

\author{
Andrzej Bąk, Lucjan Gucma \\ Akademia Morska w Szczecinie \\ e-mail:a.bak@am.szczecin.pl,l.gucma@am.szczecin.pl
}

\begin{abstract}
The method of risk assessment based on ship systems technical failures during the passage in the region of Świnoujście of the large LPG (liquefied petroleum gas) tanker is presented. The statistical reliability indicators and the simulation model of ships manoeuvring. The researches carried out within this paper let to determine the safety level and necessary tug escort service during the passage of the ship with the hazardous cargo in the port area.
\end{abstract}

Keywords: ships technical failures, navigational accidents, LPG tanker, accidents in ports

Streszczenie: $W$ artykule przedstawiono metodę oceny ryzyka wypadków na skutek awarii technicznych podczas przejścia w rejonie Świnoujścia dużej jednostki typu LPG przewożacej skroplony propan. Wykorzystano statystyczne wskaźniki niezawodnościowe oraz model symulacyjny ruchu jednostki. Przeprowadzone badania pozwolity określić niezbędne zabezpieczania $w$ postaci obstugi holowniczej podczas przejścia statku z ladunkiem niebezpiecznym $w$ rejonie portów.

Stowa kluczowe: awarie techniczne statków, wypadki nawigacyjne, zbiornikowiec $L P G$, wypadki w porcie 
The risk of striking accidents during lpg ships passage in ports in respect... Ryzyko wypadku podczas przejścia jednostek z ładunkiem niebezpiecznym...

\section{THE RISK OF STRIKING ACCIDENTS DURING LPG SHIPS PASSAGE IN PORTS IN RESPECT TO TECHNICAL FAILURES BASED ON REAL TIME SIMULATIONS IN SZCZECIN-ŚWINOUJŚCIE WATERWAY}

\section{Introduction}

It is estimated that technical failures are the cause of $10 \%$ to $20 \%$ of all accidents at sea [Gucma 2009]. However taking them into account is necessary, particularly in safety analyses of the significant consequences of possible events, for example, units carrying dangerous goods manoeuvring in the vicinity of human settlements or passenger terminals.

The aim of the work presented in the article was to determine how to protect against accidents during the passage of LPG gas tankers carrying liquefied propane to the Police during the transition in the area of the port of Świnoujście [Analiza 2015]. As a case study was adopted collision of tanker with moored boat or elements of the quays in the port of Świnoujście (called striking). Proposed the following three-stage procedure:

1) define the basic characteristics of reliability facility (LPG tanker);

2) determine the effect of a technical failure in the port of Świnoujście through the use of a simulation model of the damaged tanker LPG;

3) determination of the methods security units during the transition in the port of Świnoujście and construction of guidelines for regulations.

Two units have been analysed: current maximum and future for the so-called project of fairway Szczecin-Świnoujście "12.5 m":

1) Current tanker, so-called LPG1 with parameters: $\mathrm{Lc}[\mathrm{m}]=145 ; \mathrm{B}[\mathrm{m}]=23 ; \mathrm{T}[\mathrm{m}]=9,1$.

2) „Future” tanker, so-called. $L P G 2$ with parameters: $\mathrm{Lc}[\mathrm{m}]=220 ; \mathrm{B}[\mathrm{m}]=32 ; \mathrm{T}[\mathrm{m}]=11,0$.

The passage of tanker carrying dangerous goods through the port of Świnoujście requires special analysis due to the fact that:

1) Świnoujście is a popular resort where the season can stay more than 100 thousand people (including 60 thousand tourists);

2) has a base for sea ferries with six stations, where can stay up to 4 sea ferries at the same time;

3) has 2 local ferry (crossing the Centre and Karsibór);

4) The liquid fuels base is located there.

As an example, at 19th of September 2015 in the Świnoujście port the ninety meters Cyprus vessel carrying cellulose hit bunker barge "Palica" moored alongside passenger ferry "Baltivia" at the ferry base in Świnoujście.

The accident was an effect of steer jam. Luckily as a result of the collision only limited area of the bunker barge board was damaged (about $\left.0,5 \mathrm{~m}^{3}\right)$. 


\section{Specifying the reliability of basic equipment of the ship}

Determination of indicators of technical reliability of the ship as a technical object, composed of hundreds of thousands of items, is a very difficult task. For practical purposes, the analysis uses characteristics of reliability only a few major components. For reliability analysis the following devices are taken into account:

- the main engine (SG)

- 2 generators,

- the main rudder set,

- other.

For each of these devices can be found the reliability functions in time $R(t)$. The parameter of these functions is the failure rate at the time of $\lambda(t)$. The failure time $\lambda(t)$ may be a constant function $(\lambda(t)=$ const.) or a variable. In most analyses of marine traffic engineering, due to the need to simplify the models used and their level of abstraction, the exponential function of the reliability of constant failure is treated as sufficient approximation. On some models, you should also take into account time to repair (renewal). It is assumed that the renewal is performed by the crew of the vessel or if that is not possible by qualified shipyards and determined by a distribution of repair time. Since that time may depend on the success of the rescue operation undertaken (usually tugs, emergency stopping anchor). Rescue operation time is described by appropriate distributions.

In simple terms, the main engine can be treated as a single system and its reliability may be define as function $R_{S G}(t)=e^{-\lambda_{S G} t}$, assuming exponential time between failures. $\lambda_{S G}$ parameter value can be estimated on the basis of databases breakdown of ships, the amount is about $10^{-4}$ failures per hour of work. Main Engine (SG) is treated as a single object with its intensity of damage calculated on the base of historical data. It should also be noted the dependence of the intensity of main engine damage on the external environment, especially on the waves. Renewal time of main engine can be expressed by the exponential distribution of adequate intensity.

Ships, depending on the type and electricity demand, have from two to several power generators and the emergency one, which is located generally in the bow section of the vessel. Backup power generators operate in parallel structure and in restricted areas they work in a hot reserve regime and in coastal waters in cold. Time to start the emergency generator can also be treated as a random variable. Assuming that the time between failures has an exponential distribution of intensities $\lambda_{A i}$, reliability function $R_{A i}(t)$ for particular units can be saved as $R_{A i}(t)=e^{-\lambda_{A i} t}$. Total reliability $R_{S A}(t)$ of such a system are:

$$
R_{s A}(t)=\coprod_{i=1}^{n} R_{A i}(t)
$$


The risk of striking accidents during lpg ships passage in ports in respect... Ryzyko wypadku podczas przejścia jednostek z ładunkiem niebezpiecznym...

Main steer is a device usually driven by two hydraulic steering pumps. It is assumed that on the restricted port areas there are two working pumps, and on restricted coastal areas one is in cold reserve. In case of failure of the pumps it is possible to manually steering rudder blade. In most applications, it assumed overall reliability of the steering device as a $R_{S t}(t)=e^{-\lambda_{S t} t}$.

Rudder failure usually involves controlled pump failure or jamming of the steering mechanism. Both failures manifest themselves as immobilization of the rudder in random position, dependent on the current position. The position of the rudder before the failure can be modelled using distributions of the position of the controls. The intensity of the failure of the controls depends on the frequency pivoting of the rudder blade. This fact increases the intensity of damage to the steering system on the bends of the fairways and during mooring.

Safety systems, such as tugs, can be taken into account in the models using the distributions of time to wait for tug assistance. In the case of the emergency use of anchors possibility (suitable depth, readiness of anchors, etc.) to stop the damaged ship, analytical models of anchor impact on the ship may be used.

More complex systems are difficult to describe using the analytical methods and, therefore, for technical failures modelling of ship equipment can be used: a method of event tree and the theory of Markov chains. Figure 1 shows the tree events of technical failures of the ship (AT) for the assumption that failures can be caused by damage to the main engine (SG), rudder (St) and a set of three generating units (A). Reliability ship for such a simplified system, assuming that events are stochastically independent, can be written as:

$$
R_{s}(t)=\prod_{i=1}^{3} R_{i}(t)=R_{S G}(t) R_{S t}(t) \coprod_{i=1}^{n} R_{A i}(t)
$$

and intensity of technical failure in time as:

$$
\lambda_{s}(t)=\sum_{i=1}^{3} \lambda_{i}=\lambda_{S G}+\lambda_{S t}+\lambda_{A}
$$

Although such a model of failure is quite simplified, its level of abstraction is adapted to the needs of the research, which have an application character. The model does not include the renewal process, which in restricted areas is usually shorter than the lifetime of the system (it is not possible to repair the system before a critical failure). Restoration on coastal waters, as an alternative renewal process is simulated by using of repair time distributions, which are assumed to be exponential with parameters estimated from the Maritime Chambers decisions data, the records contained in the log books, shipyard data and expert research. 


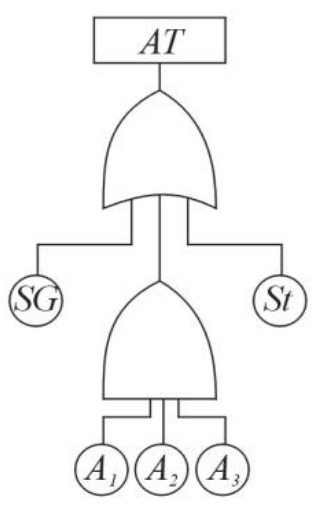

Fig.1. Tree of events for major technical failures (AT) of the ship.

Experimental determination of reliability of the main ship equipment for specialized units which are tankers for the transport of liquefied gases is not possible due to the fact that they are the specialized units, and the data are not disclosed by the ship-owners. To determine the characteristics of similar units, data from the Polish Steamship Company and Repair Yard Gryfia [Gucma and Gralak, 2007] were collected. Analysed period of 6 years (1999-2005), based on about 80 units, which at that time were operated by the PŻM. They were mostly bulk carriers but also ferries, sulphur and general cargo.

The studies assume the exponential distribution of damage and constant value of intensity of damage in the form of: $\lambda(t)=\lambda, t>0, \lambda>0$. This leads to the well-known reliability characteristics arising from the properties of a Poisson process and exponential decay in the form:

$$
\begin{gathered}
R(t)=e^{-\lambda t} \\
F(t)=1-e^{-\lambda t} \\
f(t)=\lambda e^{-\lambda t}
\end{gathered}
$$

The basic parameter here is the duration of use of the ship in the year (ie. utilization time). For a typical marine ship this time is equal to about 210 days a year. Detailed analysis of operating time are presented in [Gucma and Gralak, 2007]. In the next step two reliability events were defined in the form:

1) ship subsystem damage is adverse event involving the loss of required performance characteristics by the technical object (ship), resulting in the necessity of renewing technical measures - in this study it is defined as a failure of the main engine, generators or main helm set, that can be repaired by the crew of the ship at a certain time, so-called time of renewal,

2) technical failure of the vessel (critical damage) is an undesirable event leads to a state of unfitness, resulting in a temporary reduction of the use of the object as well as capable of contributing to the accident - in this work it is such a damage, which cannot be repaired by the ship's crew and the ship must go to the shipyards for repair. 
The risk of striking accidents during lpg ships passage in ports in respect... Ryzyko wypadku podczas przejścia jednostek z ładunkiem niebezpiecznym...

Tab. 1. The intensity of damage and failures of the ship during one year operation of the vessel and the average repair times (based on data PŻM and SR "Gryfia").

\begin{tabular}{|c|c|c|c|c|c|c|c|c|}
\hline \multirow{2}{*}{ 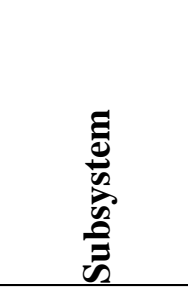 } & \multirow{2}{*}{ 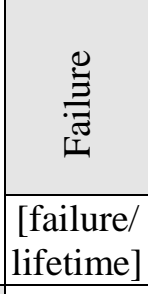 } & \multicolumn{2}{|c|}{ 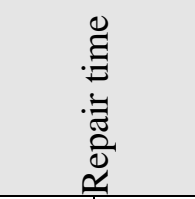 } & \multirow{2}{*}{ 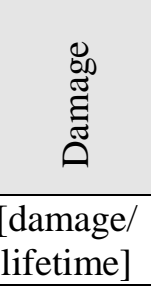 } & \multicolumn{2}{|c|}{ 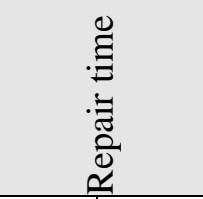 } & \multirow{2}{*}{ 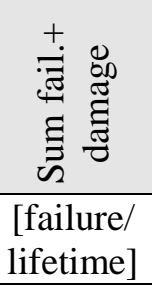 } & \multirow{2}{*}{ 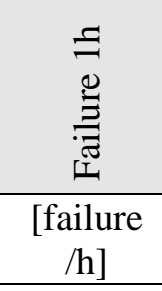 } \\
\hline & & $\begin{array}{c}\min . \\
{[\mathrm{h}]}\end{array}$ & $\begin{array}{c}\max . \\
{[\mathrm{h}]}\end{array}$ & & $\begin{array}{c}\min . \\
{[\mathrm{h}]}\end{array}$ & $\begin{array}{c}\max . \\
{[\mathrm{h}]}\end{array}$ & & \\
\hline $\begin{array}{l}\text { Main } \\
\text { engine }\end{array}$ & 0.139 & 168 & 2160 & 12.83 & 0.5 & 72 & 12.969 & 0.00257 \\
\hline Aggregate & 0.081 & 60 & 336 & 5.3 & 0.5 & 84 & 5.381 & 0.00106 \\
\hline $\begin{array}{l}\text { Other } \\
\text { critical in } \\
\text { the engine } \\
\text { room }\end{array}$ & 0.03 & 4 & 250 & 4.24 & 0.5 & 110 & 4.27 & 0.00084 \\
\hline Helm set & 0.023 & 264 & 496 & 1.1 & 0.5 & 69 & 1.123 & 0.00022 \\
\hline $\begin{array}{l}\text { Propeller } \\
\text { and } \\
\text { propeller } \\
\text { shaft }\end{array}$ & 0.053 & 24 & 1465 & - & - & - & 0.053 & $1.05 * 10^{-05}$ \\
\hline
\end{tabular}

Table 1 presents the intensity of critical damages to the ship's systems and technical failures of the ship published in the paper [Gucma and Gralak 2007]. In the analysed water area due to the very short life of the damaged system, which is a few minutes, it was assumed that both the damage and failures may result in an accident and intensity was summed (Tab.1).

For the data from Table 1 and the data from the vessel passage in the area of the port of Świnoujście (Fig. 6) the probability of failure and time between failures (Tab.2) were calculated.

Tab. 2. The probability of technical failure in port of Świnoujście.

\begin{tabular}{|l|c|c|l|}
\hline Indication & Value & Unit & \multicolumn{1}{|c|}{ Meaning } \\
\hline$\lambda_{s}=$ & 0.003864 & $1 / \mathrm{h}$ & $\begin{array}{l}\text { Total intensity of failures: ME, } \\
\text { aggregates and rudder }\end{array}$ \\
\hline$D=$ & 4000 & $\mathrm{~m}$ & Route in port of Świnoujście \\
\hline$v=$ & 2.57 & $\mathrm{~m} / \mathrm{s}$ & vessel speed $(5 \mathrm{w})$ \\
\hline$t=$ & 0.431965 & $\mathrm{~h}$ & time in Świnoujście \\
\hline$i=$ & 30 & ship/year & number of vessels per year \\
\hline$P(x>=1)=$ & 0.001668 & - & $\begin{array}{l}\text { probability of technical failure of the unit } \\
\text { in the 1 passage } P(X \geq 1)=1-e^{-\lambda t}\end{array}$ \\
\hline$n_{p}$ & 599.7 & $1 /$ passages & on how many passages there is a failure? \\
\hline$n_{t}$ & 20.0 & $1 /$ years & at how many years there is a failure? \\
\hline
\end{tabular}




\section{The simulation model of the movement of LPG vessel}

The model used to study the movement of ships is one of the modular power models, that is, one in which the hull hydrodynamic forces, propulsion systems forces, steering systems, external forces and others are distributed as separate elements of the model and in the final phase they are summed up appropriately as longitudinal, transverse and rotary ones [Gucma L., 2006]:

- propeller force,

- side force effect,

- rudders supporting and drag forces

- bow thrusters forces

- current, wind and ice influence

- forces as an effect of suction and torque of bank effect

- shallow water braking force

- mooring lines and anchors action forces

- berth reaction forces as well as friction forces between berth and a hull

- tug forces

- and others depend on the use of particular propulsion and steering devices.

\section{The equations of motion}

Fundamentals of applied mathematical model of movement manoeuvrability of the vessel (the differential equations of motion and structure depending on the function of individual external influences) are detailed, among others, in [Artyszuk, 2005] and correspond to the current state of knowledge in this field.

In simple terms (ignoring less important effects in manoeuvring process), this model can be reduced to the model in the 3 degrees of freedom, which shows the change in the speed of the ship to the bottom of the basin $\left({ }^{\mathrm{g}} \mathrm{v}^{\prime}\right)$ :

$$
\left\{\begin{array}{c}
\left(m+m_{11}\right) \frac{d v_{x}^{g}}{d t}=\left(m+c_{m} m_{22}\right) v_{y}^{g} \omega_{z}+\left(m_{11}-c_{m} m_{22}\right) v_{y}^{c} \omega_{z}+F_{x} \\
\left(m+m_{22}\right) \frac{d v_{y}^{g}}{d t}=-\left(m+m_{11}\right) v_{x}^{g} \omega_{z}+\left(m_{11}-m_{22}\right) v_{x}^{c} \omega_{z}+F_{y} \\
\left(J_{z}+m_{66}\right) \frac{d \omega_{z}}{d t}=-\left(m_{22}-m_{11}\right)\left(v_{x}^{g}-v_{x}^{c}\right)\left(v_{y}^{g}-v_{y}^{c}\right)+M_{z} \\
\frac{d x_{0}}{d t}=v_{N S}^{g} \quad, \quad \frac{d y_{0}}{d t}=v_{E W}^{g} \quad, \quad \frac{d \psi}{d t}=\omega_{z} \\
{\left[\begin{array}{l}
v_{N S}^{g} \\
v_{E W}^{g}
\end{array}\right]=\left[\begin{array}{cc}
\cos \psi & -\sin \psi \\
\sin \psi & \cos \psi
\end{array}\right] \cdot\left[\begin{array}{l}
v_{x}^{g} \\
v_{y}^{g}
\end{array}\right]}
\end{array}\right.
$$


The risk of striking accidents during lpg ships passage in ports in respect... Ryzyko wypadku podczas przejścia jednostek z ładunkiem niebezpiecznym...

where:

$v_{x}^{g}, v_{y}^{g}, \omega_{z} \quad-$ longitudinal, lateral and rotational speed,

$x_{0}, y_{0}, \psi \quad-$ coordinates and the vessel speed,

$m \quad-$ displacement (mass) of the vessel,

$m_{11}, m_{22}, m_{66}$ - accompanying masses (resulting from the movement in the of ideal fluid),

$c_{m} \quad-$ empirical factor takes into account the effects of viscosity,

$F_{x}, F_{y}, M_{z} \quad$ - the impact of external (total longitudinal, lateral and torque force), which for modelled two-screw ship (with two conventional rudders) with a double bow thruster can be decomposed into:

$$
\left\{\begin{array}{l}
F_{x}=F_{x H}+\sum_{i=1}^{2} F_{x P i}+\sum_{i=1}^{2} F_{x R i}+F_{x A}+F_{x W V 2} \\
F_{y}=F_{y H}+\sum_{i=1}^{2} F_{y P i}+\sum_{i=1}^{2} F_{y R i}+F_{y A}+F_{y W V 2}+\sum_{i=1}^{2} F_{y L T i} \\
M_{z}=M_{z H}+\sum_{i=1}^{2} M_{z P i}+\sum_{i=1}^{2} M_{z R i}+M_{z A}+M_{z W V 2}+\sum_{i=1}^{2} M_{z L T i}
\end{array}\right.
$$

Individual indexes mean:

$H \quad-$ hull,

$P \quad-$ propulsion (propeller),

$R \quad-$ Stern rudder,

$A$ - wind,

WV2 - irregular wave (forces of 2nd order, so-called drift power),

$L T$ - thruster.

The graphical interface of the model is presented in Fig. 2. It contains information about the mooring positions, bathymetry, information about the state of the ship, hydro meteorological conditions and control elements for the control the vessels.

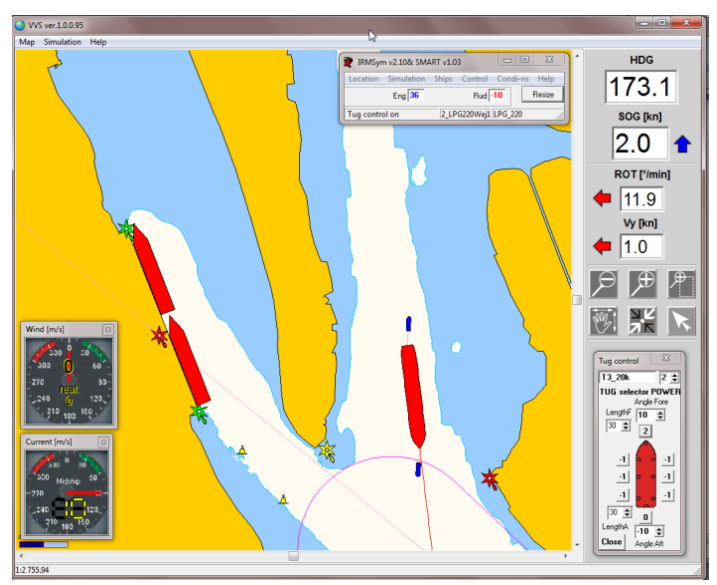

Fig. 2. The graphical interface of the simulation model of vessel traffic, ship LPG1 entering from the north to the turning place at Police (current fairway). 


\section{Research emergency scenarios in the port of Świnoujście}

Using the built and validated mathematical model [Analysis 2015] series of emergency manoeuvres were performed, whose aim was to determine the feasibility of preventing accidents by tug assistance, caused by technical failures. The aim was to verify the necessity and desirability of towing assistance in the area of the port of Świnoujście.

Examined the following two worst-case emergency scenarios:

1) jammed rudder at an angle of inclination of $20^{\circ}$ starboard without the "black out" and efficient main engine,

2) jammed rudder at an angle of inclination of $20^{\circ}$ starboard with "black out" and stop the main engine.

The following preventive manoeuvres have been applied:

1) FA on the main engine and stern tug 30T (40T for LPG2) full astern (FA).

2) STOP on the main engine (for failure "black out") and tug stern 30T (40T for LPG2) FA, tug angle $+/-10^{\circ}$ compensates for possible uncontrolled turn of the vessel.

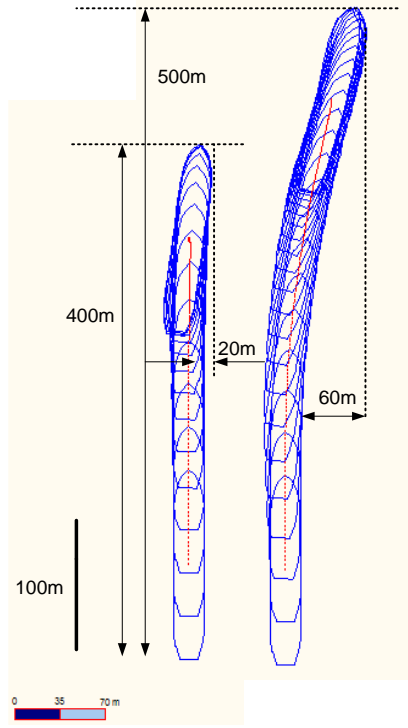

a)

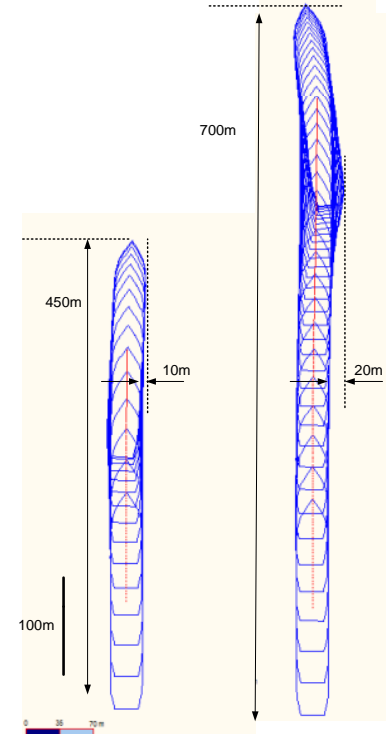

b)

Fig. 3. Emergency stop after the steer jam in $20^{\circ}$ to starboard with assistance of aft tug 30T (LPG1) and 40T (LPG2). In the left figure the Full Astern manoeuvre is presented for LPG1, while in the right Stop manoeuvre is conducted for LPG2. 
The risk of striking accidents during lpg ships passage in ports in respect... Ryzyko wypadku podczas przejścia jednostek z ładunkiem niebezpiecznym...

Using the presented model two emergency manoeuvres for LPG1 and LPG2 were performed. Emergency manoeuvres of dropping anchor wasn't used.

The emergency manoeuvre simulation results are shown in Fig. 3a and 3b. It is seen that the tug assists for pulling $30 \mathrm{~T}$ is able to stop LPG1 at distances up to $500 \mathrm{~m}$, causing the descent of the original course no greater than $60 \mathrm{~m}$. For the individual LPG2 tug assists for pulling 40T is able to keep her at a distance of up to $700 \mathrm{~m}$ off course, causing no greater than $20 \mathrm{~m}$.

Emergency situations illustrated in Fig. 4, which illustrates schematically the braking distance equal to $700 \mathrm{~m}$ and descent side of course equal to $60 \mathrm{~m}$ (maximum values obtained in the simulation). It can be noticed that in the analysed cases tanker approaching the shore, quay or moored vessel, but it must be remembered that at the end of the emergency manoeuvre she has a speed close to zero, what indicate that the use of tugs 30T and 40T for emergency assistance in Świnoujście is sufficient.

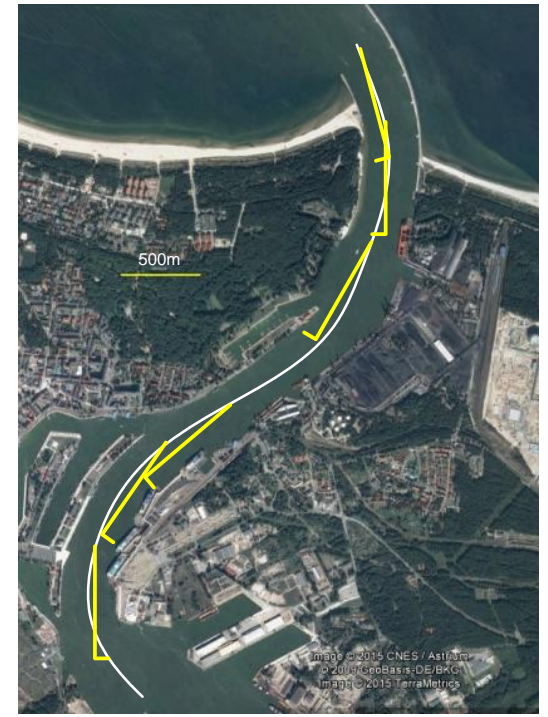

Fig.4 .Emergency scenarios for LPG 2 in Świnoujście.

\section{Conclusions}

The article presents a method of determining the probability of accidents caused by technical failures of ships on the example of vessels carrying dangerous goods in the port of Świnoujście. It is a multi-stage method, which determined reliability parameters, and then on the basis of a mathematical model of the ship are determined the effects of those emergency events.

The study confirmed that the use of tugs to assist with pulling force of $30 \mathrm{~T}$ for LPG1 and 40T for LPG2 is sufficient for even the most critical vessel failures during the passage. 
In a further step, the guidelines developed in above presented way will be included in the port regulations in order to ensure the safety of the people residing in the area of the port of Świnoujście.

There are no guidelines for acceptable levels of risk in Poland in terms of the presented in the paper. Intentionally overvalued the level of acceptance and towing assistance should practically eliminate the possibility of a collision with units moored in the port of Świnoujście.

Of course, it should be keep in mind that emergency scenarios are hardly predictable and continuous monitoring of emerging risks should be carried out, especially by analysing other events in the area.

\section{Bibliography}

[1] Analiza (2015) nawigacyjna dla infrastruktury przeładunkowej gazów płynnych w Porcie Morskiem Police wykonana metodami symulacyjnymi. Praca pod kierunkiem L. Gucma, AM Szczecin 2015.

[2] Artyszuk J. 2005, Towards a Scaled Manoeuvring Mathematical Model for a Ship of Arbitrary Size. Scientific Bulletin, Maritime University of Szczecin.

[3] Borgoń J. i inni. 1998. Symulacyjne metody do badania bezpieczeństwa lotów, SKON, Warszawa.

[4] Gucma L. 2009. Wytyczne do zarządzania ryzykiem morskim. Wydawnictwo AM w Szczecinie 2009.

[5] Gucma L. i Gralak R. (2007), Construction of the Ship's Technical Failure Model to Assess its Navigational Safety, TRANS'NAV 2007, "Advances in Marine Navigation and safety of sea transportation", Gdynia 2007.

[6] Hann M. 2005. On the Possibility of Applying Reliability Theory for the Practice of the Ship's Structural Design, II West-Pomeranian Science Congress, Marine Academy Szczecin.

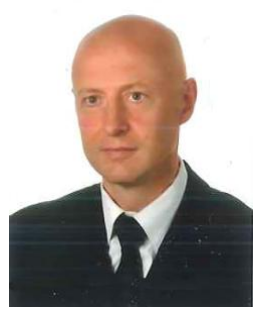

Andrzej Bak is employed as associated professor at Maritime University of Szczecin. He specialises in navigational technical systems design with special interests to ECDIS systems and its practical applications in safety management at sea.

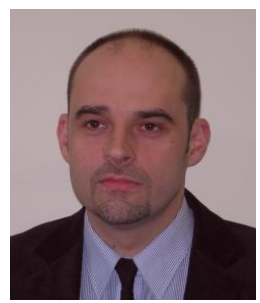

Lucjan Gucma is employed as professor at Maritime University of Szczecin He specialises in practical applications related with safety of navigation especially in costal and port areas. 
The risk of striking accidents during lpg ships passage in ports in respect... Ryzyko wypadku podczas przejścia jednostek z tadunkiem niebezpiecznym...

\section{RYZYKO WYPADKU PODCZAS PRZEJŚCIA JEDNOSTEK $Z$ LADUNKIEM NIEBEZPIECZNYM W PORTACH W ASPEKCIE AWARII URZĄDZEŃ TECHNICZNYCH NA PRZYKLADZIE JEDNOSTEK LPG MANEWRUJĄCYCH W KOMPLEKSIE PORTOWYM SZCZECIN-ŚWINOUJŚCIE}

\section{Wstęp}

Szacuje się, że awarie techniczne są przyczyną od $10 \%$ do $20 \%$ wszystkich wypadków na morzu [Gucma, 2009]. Ich uwzględnienie jest jednak konieczne, szczególnie w analizach bezpieczeństwa o znaczących konsekwencjach możliwych zdarzeń, na przykład jednostek $\mathrm{z}$ ładunkiem niebezpiecznym manewrujących w pobliżu skupisk ludzkich lub terminali pasażerskich.

Celem prac przedstawionych $\mathrm{w}$ artykule było określenie sposobu zabezpieczania przed wypadkami gazowców LPG przewożących skroplony propan do Polic podczas przejścia w rejonie portu Świnoujście [Analiza 2015]. Jako wypadek przyjęto $\mathrm{w}$ opracowaniu zderzenie zbiornikowca $\mathrm{z}$ zacumowanym statkiem lub elementami nabrzeży w porcie Świnoujście (ang. striking).

Zaproponowano następującą trzystopniową procedurę:

1) określanie podstawowych cech niezawodnościowych obiektu (zbiornikowca LPG);

2) określenie skutków awarii technicznej na terenie portu w Świnoujściu poprzez zastosowanie modelu symulacyjnego uszkodzonego zbiornikowca LPG;

3) określanie metod zabezpieczenia jednostki podczas przejścia $w$ porcie Świnoujście i budowa wytycznych do regulacji prawnych.

Analizie poddano dwie jednostki: obecną maksymalną i przyszłościową dla tzw. projektu toru wodnego Szczecin-Świnoujście „12,5m”:

1) Zbiornikowiec „obecny”, tzw. LPG1 o parametrach: $\mathrm{Lc}[\mathrm{m}]=145 ; \mathrm{B}[\mathrm{m}]=23$; $\mathrm{T}[\mathrm{m}]=9,1$.

2) Zbiornikowiec „przyszłościowy”, tzw. LPG2 o parametrach: Lc $[\mathrm{m}]=220$; $\mathrm{B}[\mathrm{m}]=32 ; \mathrm{T}[\mathrm{m}]=11,0$.

Przejście zbiornikowca $\mathrm{z}$ ładunkiem niebezpiecznym przez port w Świnoujściu wymaga specjalnych analiz z uwagi na to, że:

1) Świnoujście to popularny kurort, w którym w sezonie może przebywać nawet ponad 100 tys. osób (w tym 60 tys. turystów);

2) posiada bazę promów morskich z sześcioma stanowiskami, na której może przebywać nawet do 4 promów morskich jednocześnie;

3) posiada 2 przeprawy promowe międzybrzegowe (Przeprawa Centrum i Karsibór);

4) zlokalizowana jest tam baza paliw płynnych. 
Dnia 19.09.2015 w porcie Świnoujście 90 metrowa jednostka pod banderą cypryjska przewożąca celulozę uderzyła w bunkierkę „Palica” przycumowaną do promu „Baltivia” przy bazie promów morskich w Świnoujściu. Uderzenie było skutkiem zacięcia się steru jednostki. W wyniku kolizji szczęśliwie uszkodzeniu uległa tylko niewielka część burty bunkierki (około $0,5 \mathrm{~m}^{3}$ ).

\section{Określanie parametrów niezawodnościowych podstawowych urządzeń statkowych}

Określenie wskaźników niezawodności technicznej statku jako obiektu technicznego, złożonego z setek tysięcy elementów, jest zadaniem bardzo trudnym. Do celów praktycznych analiz wykorzystuje się charakterystyki niezawodnościowe tylko kilku najważniejszych jego urządzeń. Do analizy niezawodnościowej brane są pod uwagę takie urządzenia, jak:

- silnik główny (SG),

- generatory prądotwórcze,

- zespół steru głównego,

- inne.

Dla każdego z tych urządzeń można wyznaczyć funkcje niezawodności w czasie $R(t)$. Parametrami tych funkcji jest intensywność uszkodzeń w czasie $\lambda(t)$. Intensywność uszkodzeń w czasie $\lambda(t)$ może być funkcją stałą $(\lambda(t)=$ const.) lub zmienną. W większości analiz inżynierii ruchu morskiego, z uwagi na potrzebę uproszczenia stosowanych modeli i poziom ich abstrakcji, wystarczającym przybliżeniem jest wykładnicza funkcja niezawodności o stałej intensywności uszkodzeń. W niektórych modelach należy uwzględnić również czas naprawy (odnowę). Przyjmuje się, że odnowa wykonywana jest przez załogę statku lub jeśli taka jest niemożliwa poprzez wykwalifikowaną stocznię i określana za pomocą rozkładu czasu naprawy. Od tego czasu może zależeć powodzenie akcji ratowniczej podejmowanej z zewnątrz (najczęściej holowniki, awaryjne rzucenie kotwicy). Czas akcji ratowniczej jest opisywany za pomocą odpowiednich rozkładów.

W uproszczeniu, silnik główny można traktować jako jeden system i jego niezawodność określać funkcją $R_{S G}(t)=e^{-\lambda_{S G} t}$, zakładającą wykładniczy czas pomiędzy awariami. Wartość parametru $\lambda_{S G}$ można szacować na podstawie baz danych awarii statków, wynosi ona około $10^{-4}$ awarii na godzinę pracy. Silnik główny (SG) jest traktowany jako pojedynczy obiekt posiadający określoną na podstawie danych historycznych intensywność uszkodzeń. Należy także zauważyć zależność intensywności uszkodzeń silnika od warunków zewnętrznych, a przede wszystkim od falowania. Czas odnowy silnika głównego można wyrazić za pomocą rozkładu wykładniczego o odpowiedniej intensywności.

Statki, w zależności od typu i zapotrzebowania na energię elektryczną, mają od dwóch do kilku agregatów prądotwórczych oraz jeden awaryjny, znajdujący się $\mathrm{z}$ reguły na dziobie. 
The risk of striking accidents during lpg ships passage in ports in respect... Ryzyko wypadku podczas przejścia jednostek z ładunkiem niebezpiecznym...

Zapasowe agregaty prądotwórcze pracują w strukturze równoległej i na akwenach ograniczonych znajdują się w gorącej rezerwie, a na akwenach przybrzeżnych w zimnej. Czas uruchomienia agregatu awaryjnego można traktować również jako zmienną losową. Zakładając, że czas pomiędzy awariami ma rozkład wykładniczy o intensywnościach $\lambda_{A i}$, funkcję niezawodności $R_{A i}(t)$ dla poszczególnych agregatów można zapisać jako $R_{A i}(t)=e^{-\lambda_{A i} t}$. Całkowita niezawodność $R_{s A}(t)$ takiego układu przy założeniu, że do poprawnego funkcjonowania w czasie $t$ zespołu $n$ agregatów wystarczy conajmniej jeden agregat sprawny, wynosi:

$$
R_{s A}(t)=\coprod_{i=1}^{n} R_{A i}(t)
$$

Ster główny to urządzenie napędzane najczęściej za pomocą dwóch hydraulicznych pomp sterowych. Przyjmuje się, że na akwenach ograniczonych portowych pracują dwie pompy, a na ograniczonych przybrzeżnych jedna jest $\mathrm{w}$ zimnej rezerwie. $\mathrm{W}$ przypadku awarii obu pomp istnieje możliwość manualnego wychylania płetwy sterowej. W większości zastosowań przyjmuje się całkowitą niezawodność urządzenia sterowego jako $R_{S t}(t)=e^{-\lambda_{S t} t}$.

Awaria steru najczęściej polega na awarii pomp sterowych lub zacięciu mechanizmu sterowego. Obie awarie przejawiają się unieruchomieniem steru w pozycji losowej, zależnej od aktualnego położenia zależnego od akwenu. Położenie steru przed awarią można modelować za pomocą rozkładów położenia sterów. Intensywność awarii sterów zależy od częstości wychylania płetwy sterowej. Fakt ten powoduje zwiększenie intensywności uszkodzeń urządzeń sterowych na zakolach torów wodnych i przy manewrach podchodzenia do nabrzeży celem zacumowania.

Systemy zabezpieczające, takie jak holowniki, można uwzględniać w modelach za pomocą rozkładów czasu oczekiwania na asystę holowniczą. W przypadku możliwości awaryjnego użycia kotwic (odpowiednia głębokość, gotowość kotwic itp.) w celu zatrzymania uszkodzonego statku, można wykorzystać modele analityczne oddziaływania kotwicy na statek.

Systemy bardziej skomplikowane trudno jest opisać metodami analitycznymi i ze względu na to do modelowania awarii technicznych urządzeń statkowych mogą być wykorzystywane: metoda drzewa zdarzeń i teoria łańcuchów Markowa. Na rysunku 1. przedstawiono drzewo zdarzeń awarii technicznych statku $(A T)$ przy założeniu, że awarie mogą być spowodowane uszkodzeniami silnika głównego $(S G)$, steru $(S t)$ oraz zespołu trzech agregatów prądotwórczych $(A)$. Niezawodność statku dla tak uproszczonego systemu, przy założeniu że zdarzenia są stochastycznie niezależne, można zapisać jako:

$$
R_{s}(t)=\prod_{i=1}^{3} R_{i}(t)=R_{S G}(t) R_{S t}(t) \coprod_{i=1}^{n} R_{A i}(t)
$$

a intensywność awarii technicznych statku w czasie jako:

$$
\lambda_{s}(t)=\sum_{i=1}^{3} \lambda_{i}=\lambda_{S G}+\lambda_{S t}+\lambda_{A}
$$


Pomimo, że taki model awarii jest dość uproszczony, to jego poziom abstrakcji jest dostosowany do potrzeb przeprowadzanych badań, które mają aplikacyjny charakter. Model ten nie uwzględnia procesu odnowy, który na akwenach ograniczonych jest z reguły krótszy niż żywotność systemu (nie można dokonać naprawy systemu przed jego awarią krytyczną). Odnowa na akwenach przybrzeżnych, jako alternatywny proces odnowy, jest symulowana za pomocą rozkładów czasu naprawy, które przyjmowane są jako wykładnicze o parametrach estymowanych $\mathrm{z}$ danych orzeczeń izb morskich, zapisów zawartych $\mathrm{w}$ dziennikach okrętowych, danych stoczniowych oraz badań ekspertowych.

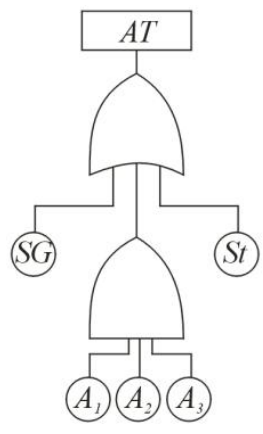

Rys. 1. Drzewo zdarzeń dla głównych awarii technicznych (AT) statku.

Określenie doświadczalne charakterystyk niezawodnościowych głównych urządzeń statkowych dla jednostek specjalistycznych jakimi są zbiornikowce do przewozu gazów skroplonych jest niemożliwe ze względu na to, że są to jednostki specjalistyczne, a dane nie są ujawniane przez armatorów. W celu określania charakterystyk podobnych jednostek zebrano dane z Polskiej Żeglugi Morskiej oraz ze Stoczni Remontowej Gryfia [Gucma i Gralak 2007]. Przeanalizowano okres 6 lat (1999-2005) bazując na około 80 jednostkach, które w tym czasie eksploatował PŻM, były to w większości masowce ale także promy, siarkowce oraz drobnicowce.

Przy badaniach założono wykładniczy rozkład pomiędzy uszkodzeniami i stałą wartość parametru intensywności uszkodzeń w postaci: $\lambda(t)=\lambda, t>0, \lambda>0$. Prowadzi to do znanych charakterystyk niezawodnościowych wynikających $\mathrm{z}$ właściwości procesu Poissona i rozkładu wykładniczego w postaci:

$$
\begin{gathered}
R(t)=e^{-\lambda t} \\
F(t)=1-e^{-\lambda t} \\
f(t)=\lambda e^{-\lambda t}
\end{gathered}
$$


The risk of striking accidents during lpg ships passage in ports in respect... Ryzyko wypadku podczas przejścia jednostek z ładunkiem niebezpiecznym...

Podstawowym parametrem czasu eksploatacji statku jest czas jego użytkowania w ciągu roku (tzw. utilization time). Czas ten wynosi średnio dla typowego statku morskiego około $210 \mathrm{dni}$ w roku. Szczegółowe analizy czasu eksploatacji przedstawiono w publikacji [Gucma i Gralak 2007].

Celem dalszych analiz zdefiniowano dwa zdarzenia niezawodnościowe w postaci:

1) uszkodzenie podsystemu statku to niepożądane zdarzenie polegające na utracie przez obiekt techniczny (statek) wymaganych właściwości eksploatacyjnych, powodujące konieczność dokonania odnawiających zabiegów technicznych - w niniejszej pracy zdefiniowano je jako uszkodzenie silnika głównego, agregatów prądotwórczych lub zespołu steru głównego, które może być naprawione siłami załogi statku w określonym czasie, tzw. czasie odnowy,

2) awarię techniczną statku (uszkodzenie krytyczne) jest niepożądanym zdarzeniem polegającym na przejściu obiektu technicznego do stanu niezdatności, powodującym czasowe ograniczenie użytkowania obiektu jak również mogącym przyczynić się do zaistnienia wypadku - w niniejszej pracy jest to takie uszkodzenie, które nie może zostać naprawione przez załoge jednostki lecz w stoczni.

W tabeli 1 przedstawiono określone w opracowaniu [Gucma i Gralak 2007] intensywności uszkodzeń krytycznych systemów statku i awarii technicznych samego statku. W analizowanym akwenie $\mathrm{z}$ uwagi na bardzo krótką żywotność systemu uszkodzonego, która jest rzędu kilku minut, przyjęto że zarówno uszkodzenia jak i awarie mogą doprowadzić do wypadku a intensywności zsumowano (tab.1).

Tab. 1. Intensywności uszkodzeń i awarii statku podczas 1 roku eksploatacji statku i uśrednione czasy naprawy (na podstawie danych PŻM i SR "Gryfia”).

\begin{tabular}{|c|c|c|c|c|c|c|c|c|}
\hline \multirow{2}{*}{$\begin{array}{l}5 \\
\frac{0}{0} \\
0 \\
0 \\
0 \\
0 \\
0\end{array}$} & \multirow{2}{*}{ 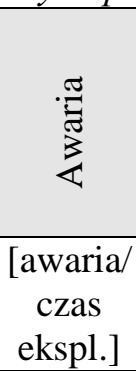 } & \multicolumn{2}{|c|}{ Uึ } & \multirow{2}{*}{ 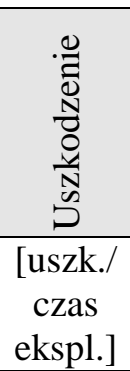 } & \multicolumn{2}{|c|}{ Ũ } & \multirow{2}{*}{ 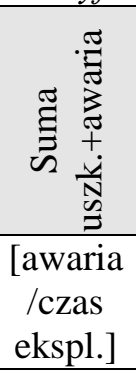 } & \multirow{2}{*}{ 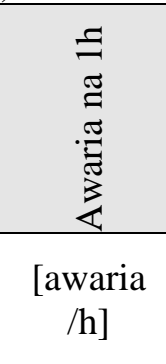 } \\
\hline & & $\min _{[\mathrm{h}]}$ & $\begin{array}{c}\text { maks. } \\
{[\mathrm{h}]}\end{array}$ & & $\min _{[\mathrm{h}]}$ & $\begin{array}{c}\text { maks. } \\
{[\mathrm{h}]}\end{array}$ & & \\
\hline $\begin{array}{l}\text { Silnik } \\
\text { główny }\end{array}$ & 0.139 & 168 & 2160 & 12.83 & 0.5 & 72 & 12.969 & 0.00257 \\
\hline Agregaty & 0.081 & 60 & 336 & 5.3 & j.w. & 84 & 5.381 & 0.00106 \\
\hline $\begin{array}{l}\text { Inne } \\
\text { krytyczne w } \\
\text { maszynowni }\end{array}$ & 0.03 & 4 & 250 & 4.24 & j.w. & 110 & 4.27 & 0.00084 \\
\hline Zespół steru & 0.023 & 264 & 496 & 1.1 & j.w. & 69 & 1.123 & 0.00022 \\
\hline $\begin{array}{l}\text { Śruba i wał } \\
\text { napędowy }\end{array}$ & 0.053 & 24 & 1465 & - & - & - & 0.053 & $1.05 * 10^{-05}$ \\
\hline
\end{tabular}


Dla danych $\mathrm{z}$ tab.1 oraz danych $\mathrm{z}$ przejścia jednostki $\mathrm{w}$ rejonie portu w Świnoujściu (rys. ostatni) obliczono prawdopodobieństwo awarii oraz czasy pomiędzy awariami (tab.2).

Tab. 2. Prawdopodobieństwo awarii technicznej jednostki w porcie Świnoujście.

\begin{tabular}{|l|c|c|l|}
\hline Oznaczenie & Wartość & Jednostka & \multicolumn{1}{|c|}{ Znaczenie } \\
\hline$\lambda_{s}=$ & 0.003864 & $1 / \mathrm{h}$ & $\begin{array}{l}\text { sumaryczna intensywność awarii: SG, } \\
\text { agregaty i ster }\end{array}$ \\
\hline$D=$ & 4000 & $\mathrm{~m}$ & droga w porcie Świnoujście \\
\hline$v=$ & 2.57 & $\mathrm{~m} / \mathrm{s}$ & prędkość jednostki (5w) \\
\hline$t=$ & 0.431965 & $\mathrm{~h}$ & czas w porcie Świnoujście \\
\hline$i=$ & 30 & st./rok & liczba statków rocznie \\
\hline$P(x>=1)=$ & 0.001668 & - & $\begin{array}{l}\text { prawdopodobieństwo awarii } \\
\text { technicznej jednostki w 1 przejściu } \\
\boldsymbol{P}(\boldsymbol{X} \geq \mathbf{1})=\mathbf{1}-\boldsymbol{e}^{-\lambda t}\end{array}$ \\
\hline$n_{p}$ & 599.7 & $1 /$ przejść & co ile przejść awaria? \\
\hline$n_{t}$ & 20.0 & $1 /$ lat & co ile lat awaria? \\
\hline
\end{tabular}

\section{Model symulacyjny ruchu jednostki LPG}

Model wykorzystany do badania ruchu statków należy do modeli siłowych o konstrukcji modułowej to jest takiej, w której siły hydrodynamiczne kadłuba, siły od urządzeń napędowych, sterowych, siły zewnętrzne i inne są rozdzielone jako osobne elementy modelu i w końcowej fazie odpowiednio sumowane jako siły wzdłużne, poprzeczne i obrotowe [Gucma L. 2006]:

- naporu śrub,

- działania bocznego śrub,

- nośne i oporu sterów,

- działania sterów strumieniowych,

- prądu, wiatru i lodów,

- ssąca i moment skręcający efektu brzegowego,

- hamująca płytkowodzia,

- działania cum i kotwic,

- reakcji nabrzeża i tarcia pomiędzy nabrzeżem i kadłubem statku,

- od holowników,

- oraz inne wynikające ze specyfiki konkretnych urządzeń napędowych i sterowych.

\section{Równania ruchu}

Podstawy zastosowanego matematycznego modelu ruchów manewrowych jednostki pływającej (różniczkowe równania ruchu oraz struktura zależności funkcyjnych poszczególnych oddziaływań zewnętrznych) zostały szczegółowo przedstawione m.in. w [Artyszuk, 2005] i odpowiadają aktualnemu stanowi wiedzy w tej dziedzinie. 
The risk of striking accidents during lpg ships passage in ports in respect... Ryzyko wypadku podczas przejścia jednostek z ładunkiem niebezpiecznym...

W uproszczeniu (pomijając mniej istotne $\mathrm{w}$ manewrowaniu efekty) powyższy model można sprowadzić do następującego w 3 stopniach swobody, który pokazuje zmianę prędkości statku względem dna akwenu (' $\left.v^{g}\right)$ :

$$
\left\{\begin{aligned}
&\left(m+m_{11}\right) \frac{d v_{x}^{g}}{d t}=\left(m+c_{m} m_{22}\right) v_{y}^{g} \omega_{z}+\left(m_{11}-c_{m} m_{22}\right) v_{y}^{c} \omega_{z}+F_{x} \\
&\left(m+m_{22}\right) \frac{d v_{y}^{g}}{d t}=-\left(m+m_{11}\right) v_{x}^{g} \omega_{z}+\left(m_{11}-m_{22}\right) v_{x}^{c} \omega_{z}+F_{y} \\
&\left(J_{z}+m_{66}\right) \frac{d \omega_{z}}{d t}=-\left(m_{22}-m_{11}\right)\left(v_{x}^{g}-v_{x}^{c}\right)\left(v_{y}^{g}-v_{y}^{c}\right)+M_{z} \\
& \frac{d x_{0}}{d t}=v_{N S}^{g} \quad, \quad \frac{d y_{0}}{d t}=v_{E W}^{g} \quad, \quad \frac{d \psi}{d t}=\omega_{z} \\
& {\left[\begin{array}{l}
v_{N S}^{g} \\
v_{E W}^{g}
\end{array}\right]=\left[\begin{array}{cc}
\cos \psi & -\sin \psi \\
\sin \psi & \cos \psi
\end{array}\right] \cdot\left[\begin{array}{c}
v_{x}^{g} \\
v_{y}^{g}
\end{array}\right] }
\end{aligned}\right.
$$

gdzie,

$v_{x}^{g}, v_{y}^{g}, \omega_{z} \quad-$ prędkość wzdłużna, poprzeczna i obrotowa,

$x_{0}, y_{0}, \psi \quad-$ współrzędne pozycji i kurs jednostki

$m \quad-$ wyporność (masa) jednostki,

$m_{11}, m_{22}, m_{66}-$ masy towarzyszące (wynikające z ruchu w cieczy idealnej),

$c_{m} \quad-$ współczynnik empiryczny uwzględniający efekty lepkościowe,

$F_{x}, F_{y}, M_{z} \quad$ - oddziaływania zewnętrzne (całkowita siła wzdłużna, poprzeczna i moment obrotowy), które dla modelowanego statku dwuśrubowego (z dwoma sterami konwencjonalnymi) z podwójnym dziobowym sterem strumieniowym można rozłożyć na:

$$
\left\{\begin{array}{l}
F_{x}=F_{x H}+\sum_{i=1}^{2} F_{x P i}+\sum_{i=1}^{2} F_{x R i}+F_{x A}+F_{x W V 2} \\
F_{y}=F_{y H}+\sum_{i=1}^{2} F_{y P i}+\sum_{i=1}^{2} F_{y R i}+F_{y A}+F_{y W V 2}+\sum_{i=1}^{2} F_{y L T i} \\
M_{z}=M_{z H}+\sum_{i=1}^{2} M_{z P i}+\sum_{i=1}^{2} M_{z R i}+M_{z A}+M_{z W V 2}+\sum_{i=1}^{2} M_{z L T i}
\end{array}\right.
$$

Poszczególne indeksy oznaczają:

$H \quad-$ kadłub,

$P \quad$ - pędnik (śruba okrętowa),

$R \quad-$ ster rufowy,

$A \quad-$ wiatr,

WV2 - fala nieregularna (siły 2.rzędu tzw. siły dryfu),

$L T$ - ster strumieniowy. 
Interfejs graficzny modelu przedstawiono na rys. 2. Zawiera on informacje o położeniu stanowiska, batymetrie akwenu, informacje o stanie statku i warunkach hydrometeorologicznych oraz elementy kontrolne do sterowania jednostką.

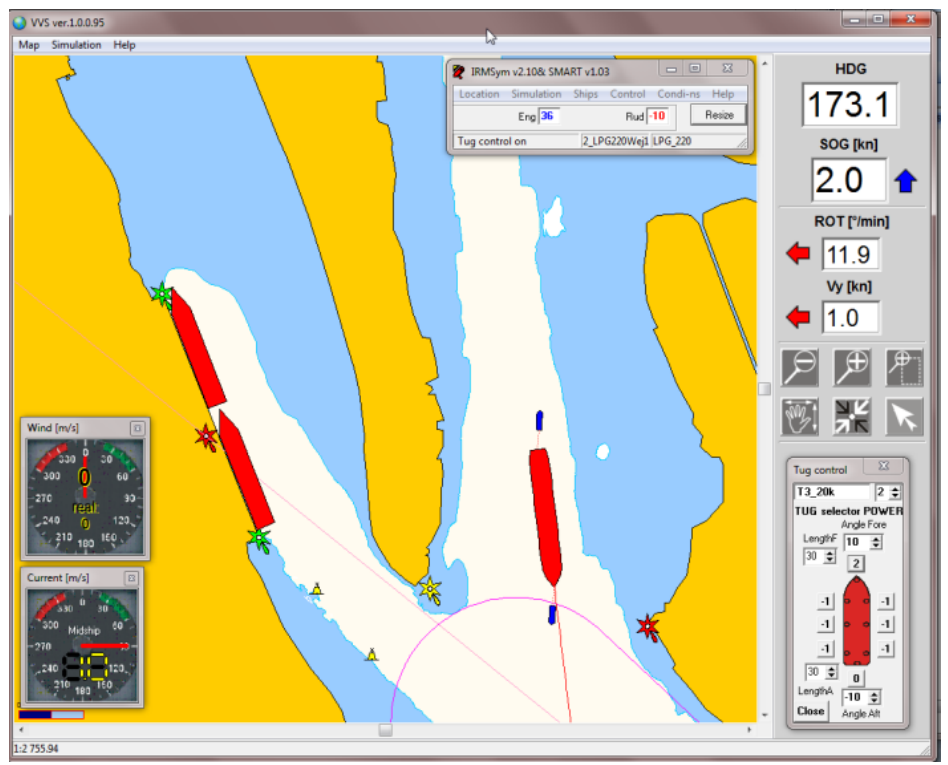

Rys. 2. Interfejs graficzny modelu symulacyjnego ruchu statków, statek LPG1 wchodzacy od pótnocy na Obrotnicę Policka (tor aktualny).

\section{Badanie scenariuszy awaryjnych w porcie Świnoujście}

Za pomocą zbudowanego i zweryfikowanego modelu matematycznego [Analiza 2015] Wykonano serie manewrów awaryjnych, których celem było określenie możliwości zapobiegania wypadkom powstałym w wyniku awarii technicznych za pomocą asystującego holownika. Celem ich było sprawdzenie konieczności i celowości asysty holowniczej w rejonie portu w Świnoujściu.

Zbadano dwa następujące najgorsze scenariusze awaryjne (tzw. worst case scanario):

1) zacięcie steru przy kącie wychylenia $20^{\circ} \mathrm{PB}$ bez „black out” i sprawnym silniku głównym,

2) zacięcie steru przy kącie wychylenia $20^{\circ} \mathrm{PB} \mathrm{z}$ „black out” i zatrzymaniem silnika głównego.

Stosowano następujące manewry zapobiegawcze:

- CW, na silniku głównym oraz holownik rufowy 30T (40T dla LPG2) cała moc wstecz.

- STOP na silniku głównym (dla awarii „black out”) oraz holownik rufowy 30T (40T dla LPG2) cała moc wstecz, kąt holownika $+/-10^{\circ}$ kompensuje ewentualny niekontrolowany zwrot jednostki. 
The risk of striking accidents during lpg ships passage in ports in respect... Ryzyko wypadku podczas przejścia jednostek z tadunkiem niebezpiecznym...

Za pomocą przedstawionego modelu wykonano dwa manewry awaryjne dla LPG1 i LPG2. Nie stosowano manewrtawaryjnego rzucenia kotwicy.

Wyniki symulacji manewru awaryjnego pokazano na rys. 3.A i 3.B. Widać z nich że, holownik asystujący o uciągu 30T jest w stanie zatrzymać LPG1 na odległości do $500 \mathrm{~m}$ powodując zejście pierwotnego kursu nie większe niż $60 \mathrm{~m}$. Dla jednostki LPG2 holownik asystujący o uciągu 40T jest w stanie zatrzymać ją w odległości do $700 \mathrm{~m}$ powodując zejścia z kursu nie większe niż $20 \mathrm{~m}$.

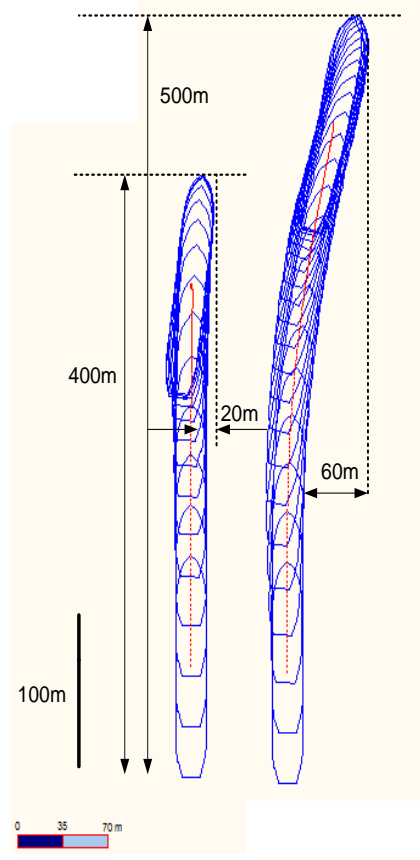

A.

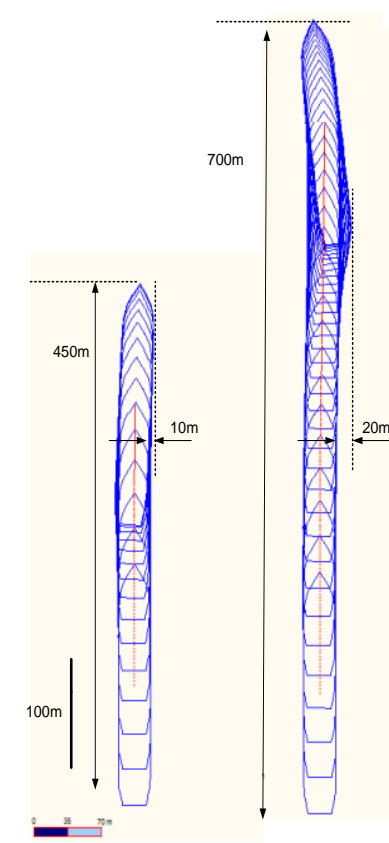

B.

Rys. 3. Zatrzymanie awaryjne przy zacięciu steru $20^{\circ}$ na burtę z użyciem rufowego holownika 30T (LPG1)i 40T (LPG2) z manewrem CW (lewa sylwetka) oraz STOP (prawa sylwetka) dla LPG1 (A) i LPG2 (B).

Sytuacje awaryjne zobrazowano na rys. 4 gdzie przedstawiono schematycznie odległość hamowania równą $700 \mathrm{~m}$ i zejście boczne $\mathrm{z}$ kursu równą $60 \mathrm{~m}$ (maksymalne wartości uzyskane $\mathrm{w}$ symulacjach). Widać, że $\mathrm{w}$ analizowanych przypadkach zbiornikowiec wprawdzie zbliża się do brzegu, nabrzeży lub zacumowanych statków, ale należy pamiętać, że pod koniec manewru awaryjnego ma prędkości bliskie zeru co wskazuje, że użycie holowników 30T i 40T do asysty awaryjnej w Świnoujściu jest wystarczające. 


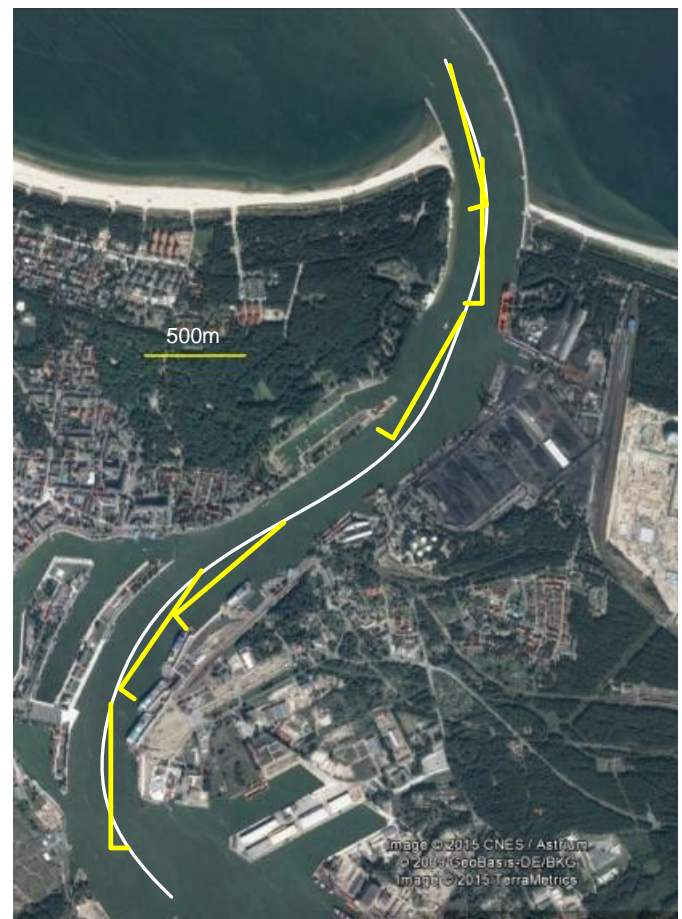

Rys. 4. Scenariusze awaryjne dla LPG2 w Świnoujściu.

\section{Wnioski}

W artykule przedstawiono metodę określania prawdopodobieństwa wypadków powstałych $\mathrm{w}$ wyniku awarii technicznych statków na przykładzie jednostek z ładunkiem niebezpiecznym w porcie Świnoujście. Jest to metoda wieloetapowa, w której określane są parametry niezawodnościowe, a potem na bazie modelu matematycznego statku określane są skutki tych zdarzeń awaryjnych.

W pracy potwierdzono, że wykorzystanie asysty holownika o uciągu 30T dla LPG1 i 40T dla LPG2 jest wystarczająca nawet przy najbardziej krytycznych uszkodzeniach jednostek podczas przejścia.

Zbudowane $\mathrm{w}$ ten sposób wytyczne trafią $\mathrm{w}$ dalszym kroku do przepisów portowych po to aby zapewnić bezpieczeństwo ludziom przebywających w rejonie portu w Świnoujściu.

$\mathrm{Z}$ racji braku wytycznych do poziomów ryzyka akceptowalnego w Polsce $\mathrm{w}$ zakresie przedstawianym $\mathrm{w}$ opracowaniu, celowo zawyżono poziom jego akceptacji, a asysta holownicza praktycznie powinna wyeliminować możliwość zderzenia z zacumowanymi jednostkami w porcie Świnoujście.

Oczywiście należy pamiętać, że scenariusze awaryjne są trudno przewidywalne i należy prowadzić ciągły monitoring powstających zagrożeń, szczególnie analizując inne wypadki w tym rejonie. 
The risk of striking accidents during lpg ships passage in ports in respect... Ryzyko wypadku podczas przejścia jednostek z ładunkiem niebezpiecznym...

\section{Literatura}

[1] Analiza (2015) nawigacyjna dla infrastruktury przeładunkowej gazów płynnych w Porcie Morskiem Police wykonana metodami symulacyjnymi. Praca pod kierunkiem L. Gucma, AM Szczecin 2015.

[2] Artyszuk J. 2005, Towards a Scaled Manoeuvring Mathematical Model for a Ship of Arbitrary Size. Scientific Bulletin, Maritime University of Szczecin.

[3] Borgoń J. i inni. 1998. Symulacyjne metody do badania bezpieczeństwa lotów, SKON, Warszawa.

[4] Gucma L. 2009. Wytyczne do zarządzania ryzykiem morskim. AM w Szczecinie 2009.

[5] Gucma L. i Gralak R. (2007), Construction of the Ship's Technical Failure Model to Assess its Navigational Safety, Materiały konferencyjne TRANS'NAV 2007, "Advances in Marine Navigation and safety of sea transportation", Gdynia 2007.

[6] Hann M. 2005. On the Possibility of Applying Reliability Theory for the Practice of the Ship's Structural Design, II West-Pomeranian Science Congress, Marine Academy Szczecin.

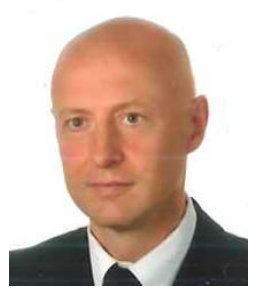

Andrzej Bak jest zatrudniony na stanowisku profesora nadzwyczajnego w Akademii Morskiej w Szczecinie. Specjalizuje się $w$ elektronicznych systemach nawigacyjnych oraz ich praktycznym wykorzystaniem $w$ systemach zarzadzania bezpieczeństwem.

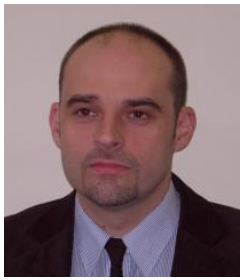

Lucjan Gucma jest zatrudniony na stanowisku profesora w Akademii Morskiej w Szczecinie. Specjalizuje sie $w$ praktycznych aplikacjach zwiazanych $z$ bezpieczeństwem nawigacji szczególnie na akwenach portowych i przybrzeżnych. 